\title{
Ottoman Decline: Military Adaptation in the Ottoman Empire, 1683-1699
}

\author{
Stewart Kerr ${ }^{\mathrm{a}}$, Ian Germani ${ }^{\mathrm{a}}$
}

\begin{abstract}
The Siege of Vienna in 1683 by the Ottoman army marks a key shift in the rise and fall of the Ottoman Empire. The power of the Ottomans had continuously risen since 1453 but the defeat of the Ottoman army at Vienna marked the beginning of Ottoman decline in military and geographical power. The years following the siege forced the Ottomans to fight a united alliance of Austrian, Venician, and Polish armies from Europe. This article follows the events from the siege of Vienna through to the year 1699, when the war following the siege, finally came to an end with the Ottomans seceding land to all three of its European opponents. By tracing the academic debate on what impacted the Ottoman defeat the most, the article explores the different theories behind why the Ottomans were defeated and what were the causes for the shift in power away from the Ottoman Empire and towards the countries in Europe.
\end{abstract}

Keywords: Ottoman Empire History; Siege of Vienna; European History, Military History

The Ottoman Empire is one of the longest lasting empires in history. At its peak it stretched from Hungary in Eastern Europe to modern day Iraq and Saudi Arabia, to the Mediterranean coast of North Africa. It controlled the trade and administration of such famous cities as Athens, Jerusalem, Mecca, Medina, Belgrade, Cairo, Babylon, and of course its capital Istanbul which it had captured from the Byzantines in 1453. The Empire lasted until 1923 and was a player in world politics and trade for more than six centuries. With such a long history, there has been much discussion and debate between scholars regarding the effects and impact of several significant periods within the history of the Ottoman Empire. The siege of Vienna in 1683 and the subsequent War of the Holy League that concluded in 1699 with the Treaty of Carlowitz is one of these significant events in Ottoman history. The years from 1683 to 1699 have been studied and analyzed by scholars as potentially a key turning point in Ottoman history when the Ottoman Empire shifted from a lengthy period of expansion to an equally drawn-out phase of decline. Consequently, the identification of 1683 to 1699 being a period of Ottoman decline has sparked a variety of viewpoints from scholars who identify a combination of European strengths and Ottoman weaknesses in their explanation behind the cause of the Ottoman decline. Upon analysis of the primary and secondary sources dealing with this period of European-Ottoman history, the decline of the Ottoman Empire began with increased European military strength and the European alliance dealing several defeats to the Ottomans whose attempt to adapt to these events led to the destabilizing of their empire.

A Turning Point for the Ottoman Empire: From the Siege of Vienna (1683) to the Treaty of Carlowitz (1699).

Up until 1683 the Ottomans were feared by Europeans. It is of no surprise that on 14 July 1683, terror gripped the city of Vienna when a vast Ottoman horde, almost one hundred thousand strong, advanced toward the city to besiege it. Not only the fate of Vienna but that of the whole of Eastern Europe hung in the balance. The stakes were high for the leaders of both sides. King Leopold of Vienna had fled the city, as was usual for a king when his capital was besieged and was seeking military aid from other European countries. On the opposite side, Kara Mustafa, the Grand Vizier of the
Ottoman Turks, had concentrated the might of the Ottoman army on one siege of the Habsburg capital in an attempt to become a legend in Ottoman history. A loss on either side would be devastating.

The Ottoman army moved around the city of Vienna in the shape of a crescent moon. ${ }^{1}$ The Ottomans brought siege cannon, supply wagons, supply camels, and two centuries of experience in siege warfare. Stretching from the Danube River around the main bastion in Vienna and into the open field surrounding the city, the Ottomans began to work on siege trenches while the town of Vienna readied its cannon and prepared for the onslaught. Many fled the city before the Ottomans had encircled Vienna but many of these fleeing citizens were hunted down by the Tatars, ferocious auxiliary cavalry of the Ottoman army, and were either captured or killed. The next two months of fighting that took place at Vienna would reveal some of the most horrific fighting and horrors that war had to offer.

Inside the city of Vienna, the troops and city militias were organized into individual companies commanded by military officers. Two hundred and fifty men were chosen to be trained for fighting fires, and even the local university students were organized into three companies of 236 each. $^{2}$ The trenches dug by the Turks toward the dike surrounding Vienna would be the location for the most grueling combat that took place during the siege. For the next two months, this was the location of countless skirmishes waged with spade and shovel in suffocating tunnels that stank of rotting flesh and decomposing bodies. ${ }^{3}$ With the explosion of underground mines packed with explosives, the trenches became an area of unpredictable death for soldiers who could have limbs blown

${ }^{1}$ Crescent moon is the description given by Vaelckern, an officer in the Habsburg army who witnessed the siege from inside the walls of Vienna. Johann Peter von Vaelckern, A Relation or Diary of the Siege of Vienna (New York: Union Theological Seminary, 1684), 27.

${ }^{2}$ Ibid., 25.

3 Archer, Christon, John R. Ferris, Holger H. Herwig, Timothy H. E. Travers. A World History of Warfare (New York: University of Nebraska Press, 2008), 281. 
off at any time. The soldiers of Vienna had prepared for the fighting with granadios, long spear like hooks designed to hook Ottomans fighter around the neck which had been designed to fight in the trenches used by Ottomans at sieges. ${ }^{4}$

In addition to the war in the trenches, both sides exchanged mortar and cannon fire on a daily basis. The Turks responded to the city's cannon fire by burrowing deeper into the ground; likewise, the chosen fire fighters inside Vienna managed to keep the fires caused by the Turkish mortars under control. Citizens of Vienna who ventured too far into sight atop the protective wall were dangerously exposed to cannon fire and musket fire. Ottomans scampering among the trench works were in danger of being picked off by musket fire from the wall by the Viennese sharpshooters scattered among the defenders of the city. The battlefield consisted of few safe areas, in that both attackers and defenders could at any time be blown up by a mine or killed by a mortar shot falling from the sky. ${ }^{5}$

Subsequently, the defenders of Vienna had great success in night attacks on the Ottoman positions. Successes ranged from burning Ottoman boats on the Danube River, driving Ottoman oxen and other animals into the city of Vienna, and attacks made on the Ottoman trench works. Even though these attacks resulted in heavy losses on both sides it was a great moral victory for the city defenders because they succeeded in halting the progress of the Ottoman sappers ${ }^{6}$ Despite these successful night attacks, Vienna was weakening, and the city leaders gradually realized that the city could not hold out for much longer. The site of the Imperial army from atop Saint Stephen's Tower inside the city gave the defenders hope that a relief army was on its way, ${ }^{7}$ but, would it come to Vienna's aid in time?

\footnotetext{
${ }^{4}$ The soldiers of Vienna had prepared for the fighting with granadios, long spear like hooks used to hook a Ottoman fighter around the neck and designed to fight in the trenches used by Ottomans at sieges. Vaelckern describes a scene when the Ottomans had carried on their mining operations toward the ditch that they came in contact with some of the defenders who used the iron hooks they had been using in their counter mining operations to pull the Ottoman soldiers further into the trench and in range of a sword stab. Vaelckern, Johann Peter von. A Relation or Diary of the Siege of Vienna (New York: Union Theological Seminary, 1684), 46.

${ }^{5}$ A description of a time when a bomb thrown by a Ottoman soldier set fire to a mortar piece inside the city effectively setting off the bomb placed inside the mortar which, to the surprise of both armies, did great damage to the Ottoman attackers in the trenches. The amount of surprise explosions from mines and mortars like in this instance made the city and surrounding area a death zone with few secure locations. Ibid., 46-47.

${ }^{6}$ Ibid., 49-57. Andrew Wheatcroft,. The Enemy at the Gate: Habsburgs, Ottomans and the Battle for Europe.

(Np: Vintage Digital, 2009), 147.

7 Vaelckern, Johann Peter von. A Relation or Diary of the Siege of Vienna (New York: Union

Theological Seminary, 1684), 54.
}

Although the will of Vienna was showing signs of breaking, the defenders of the city maintained the determination to fight. The stories of taken Habsburg fortresses by the Ottomans, in which the Habsburg residents were either slaughtered or taken into slavery regardless of age or sexuality were burned into the minds of the Viennese defenders. The choice was either die defending the city or die as an Ottoman captive.

Vienna continued to hold out and managed to find a way to communicate with the Duke of Lorraine, the leader of the Imperial Field Army. On the 21 August an Ottoman defector came into the city and told defenders that the Ottomans were preparing for a large concentrated assault. ${ }^{8}$ The concentrated assault was inevitable considering the relief force for the city was starting to mobilize on the other side of the river. The next seven days witnessed an even greater intensification of the fighting. The situation on both sides became dire and morale on both sides was showing signs of breaking. On 28 August the city of Vienna shot a rocket into the air to signal the Duke of Lorraine to hasten his relief. ${ }^{9}$ The Ottoman army, whose progress had been slow and steady, were beginning to doubt their ability to break the city before time was up.

By September, the relief force had finally begun their plans of attack on the Ottoman siege force. The allied force was approximately 46,000 soldiers. Consisting of Polish, Habsburg, Bavarian, and smaller German speaking members of the Holy Roman Empire, the relief force was led by King John Sobieski III of Poland and the Duke of Lorraine. A war council was held by the relief force to decide what day an attack on the Ottoman position should be carried out and it was decided that the 8 September would be the day of the allied attack. ${ }^{10}$ The relief force took up their position in the mountains behind the center of the Ottoman position. Several selected locations on the battlefield were secured by the relief force as fortified cannon bombardment locations. The battle to save Vienna was about to begin.

At dawn the relief force began their bombardment on the Ottoman position. The two armies, one led by the King of Poland and the other led by the Duke of Lorraine, charged forward mercilessly, killing all Ottoman soldiers who stood in their path. Once their lines were broken the Ottomans quickly fled the battlefield. One witness described the scene of fleeing Ottomans, saying "it is impossible to describe adequately the confusion, destruction, and panic of those countless barbarians." 11 The relief force in less than a day had won victory over the Ottomans who had been caught off guard and ill-prepared for a direct attack on their lines. The Christian forces continued the attack on the Ottomans until dusk. The next day the killing of Ottomans continued. The Polish continued their pursuit of the Ottoman infantry; meanwhile Ottoman sappers who had been working in the mines

\footnotetext{
${ }^{8}$ Ibid., 71.

${ }^{9}$ Ibid., 79.

10 Anon., The Siege of Vienna by the Turks in 1683: Translated into Greek from an Italian Work Published Anonymously in the Year of the Siege, trans. by Jeremias Cacavelas (New York: Cambridge University Press, 1925), 107.

${ }^{11}$ Ibid., 121.
} 
underground came out of their holes to report on their work only to be met by the swords of the Christians and put to death. ${ }^{12}$ The successful relief of Vienna was a great victory for the Habsburgs and their allies. It marked the beginning of a war that would witness many Ottoman defeats at the hands of their European Christian enemies.

The victory at Vienna resulted in widespread celebration throughout Europe. Poems and ballads were written describing the great victory, calling it the greatest victory against the Turks since the foundation of the Ottoman Empire. ${ }^{13}$ This high morale quickly turned into religious fervor as a Christian alliance was formed to begin a new crusade to take back territory from the Ottoman Empire. This new crusade received help from Pope Innocent XI who helped form the Holy League Alliance by calling on all Christians of Europe to help in the attack against the Eastern Infidels, and helped finance the war by sending large amounts of money to the alliance's leaders. ${ }^{14}$ With the Ottoman territory now exposed, a Christian army besieged Buda, the capital of Hungary, in 1684 but failed to capture the city. A second attempt was tried in 1686 with an army led by the Duke of Lorraine who was this time victorious.

The army that besieged Buda in 1686 was an example of Christian nations answering the call from the Pope to take up arms against the Ottomans. The Duke of Lorraine's army, consisting of soldiers from Brandenburg, Spain, and England, with financial support from the Pope, captured Buda after a siege of seventy-eight days. After the capture of Buda, Venetian and Polish armies continued to put pressure on the Ottomans by pushing into the Ottoman held territories of Moldovia, and Ottoman controlled islands in the Mediterranean. As a result of European victories at Buda and on other borders of the Ottoman Empire the Christian alliance strengthened and continued to receive support from other Christian nations and the Pope for several more years. ${ }^{15}$

Many Christians fighting the Ottomans expressed their belief that the Christian victories were a sign of favor with God and that the conquest of Ottoman land should be continued. An eye witness to these events argued that the capture of Buda should be followed up by marching on Belgrade: "when in a Council of War it was received that seeing Buda was already reduced, and Heaven signally favoured the Christian army, it was not convenient to omit the opportunity of besieging so important a place the Infidels

\footnotetext{
12 Ibid., 133.

13 The Bloody Siege of Vienna A song wherein the Turks have lost One Hundred and Sixty Thousand Men; being the greatest victory that was ever obtained over the Turks since the Foundation of the Ottoman Empire was the title of a poem written by an English gentleman that was garrisoned at Vienna during the siege.

${ }^{14}$ Bennridge, Will. An Historical description of the glorious conquest of the city of Buda,. (London: Printed for Robert Clavell, 1686), 4.

${ }^{15}$ Ibid., 4.
}

held." ${ }^{, 16}$ In 1688 an army led by Maximillian II of Bavaria laid siege to the city of Belgrade. The siege only lasted twenty four days before the city of Belgrade was surrendered to the Christian forces. The Ottomans had suffered a major military defeat at the Battle of Darda in 1687. The defeat, combined with the political and social turmoil already setting in with the Ottoman army, left the Ottoman defensive network of fortresses easy targets for the advancing European armies. It seemed like the Ottomans would never be able to stop the European advance into territory they had held for over a century. In 1689 the European advance slowed. However, the Christian armies were not stopped by Ottoman forces but rather French advances into German speaking lands diverted Habsburg attention away from their eastern border with the Ottomans and toward the German-French border.

With the Habsburg armies active in Western Europe the opportunity for an Ottoman counter offensive seemed like a plausible idea but the Ottomans struggled to take advantage of the situation because of political and social turmoil that existed within the empire. This turmoil escalated in 1687 with a military coup to depose Sultan Mehmed IV from the throne. He was replaced with his brother who was crowned Mustafa II and would remain Sultan until 1703. Europe's attention being directed toward France in 1689 and the Ottoman revolts in the capital city of Istanbul resulted in a period of six years of little fighting between the two groups. The European momentum had been stopped and the Ottoman turmoil prevented a counter offensive. However in 1696 the fighting between the two groups would resume this time with new military leaders and for the Ottomans a new Sultan.

At this time, a new Ottoman military reorganized under a new Grand Vizier and a new Sultan faced off against the Habsburg army led by Eugene of Savoy at the Battle of Zenta. The Battle of Zenta would be a decisive victory for the Habsburg army. Eugene of Savoy describes a moment of the battle when the slaughter of the Turks was most fierce. "The Turks assaulted, and their entrenchments forced in all points, hurried in crowds to the bridge and choked it up, so that they were obliged to throw themselves into the Teisse, where those who escaped drowning were killed."17 The Habsburg victory at Zenta saw the destruction of the main Ottoman army for the second time, the first being the victory at Vienna in 1683. The European forces would enjoy another two years of territorial gain until 1699 when the treaty of Carlowitz was signed between Venice, Poland, the Habsburgs, and the Ottomans.

\footnotetext{
${ }^{16}$ Anon., A True Relation or Journal of the Siege and Taking by Storm of the Famous City of Belgrade by the Christian army under the conduct of the victorious elector of Bavaria, on the $6^{\text {th }}$ day of September 1688: with an account of its situation, fortifications, \&c., and also of the great victory gained by Prince Lovis of Baden over the Turkish army, commanded by the Bassa of Bosnia (London: Printed for Richard Baldwin, 1688), 4.

${ }^{17}$ Prince Eugene of Savoy. Memoirs of Prince Eugene of Savoy, trans. by Mudford William (London: Printed for Henry Colburn, 1811), 49-50.
} 
The treaty of Carlowitz signed on 26 January 1699 ended the War of the Holy League. Consisting of three parts Austria and Ottoman relations, Poland and Ottoman relations, and Venetian and Ottoman relations - the treaty outlined the terms and conditions to end the war. Most notably the Treaty allowed for free trade, freedoms given to the Catholic Church within the Ottoman Empire, and rules pertaining to giving sanctuary or support to the criminals of another country. ${ }^{18}$ The Ottomans had begun the War of the Holy League with the siege of Vienna in 1683 where they threatened the Eastern border of Europe. By 1699 and the Treaty of Carlowitz they had suffered major losses in territory gained from earlier wars with European nations. With the signing of the treaty of Carlowitz the Ottomans had to concede the control of Moldavia and Wallachia to Poland, Hungary and Transylvania to the Habsburgs, and the Morea lands to the city state of Venice. ${ }^{19}$ The Ottoman Empire had gone from a mighty empire feared by Europe to a decomposing empire that showed weakness and inability to withstand the European advance into its territory.

In view of the story told by these primary sources, analysis of the language used by the European eyewitnesses reveals an element of praise for the Christian God and the European fighters while also demonizing and expressing notions of Islamic inferiority. Jeremias Cacavelas's description of the siege and the relief of Vienna ascribes the victory to an act of God because of the accepted plea to the king of Poland to come help. Cacavelas refers to the king of Poland as "the scourge of the barbarians, the soldier of Christ, the defender of the Gospel, and the liberator of Germany and all of Europe." 20 Furthermore, the created alliance of Christian nations is seen as an act of God to carry out his punishment on the Ottomans for the breaking of a peace treaty two years before its expiration. ${ }^{21}$ Under these circumstances, the Christian nations of Europe saw themselves as instruments for God's punishment of the Ottomans and for the relief of Eastern Europe from Ottoman treachery. Consequently, the writing of the eyewitnesses of the time period was romanticized to express courage and exceptional soldiering by the European fighters. The events and witnesses of the events from 1683 to 1699 in the War of the Holy League tell a story of Ottoman decline and provide many reasons for it. This has

18 Treaty of Carlowitz, 1699. Documents Archive. www.fas.nus.edu.sg [Âccessed 10 March, 2016].

${ }^{19}$ Ibid.

${ }^{20}$ Cacavelas, Jeremias, Trans. The Siege of Vienna by the Turks in 1683: Translated into Greek from an Italian Work Published Anonymously in the Year of the Siege. (New York: Cambridge University Press, 1925), 129.

${ }^{21}$ Bennridge, Will. An Historical description of the glorious conquest of the city of Buda, the capital city of the kingdom of Hungary, by the victorious arms of the thrice illustrious and invincible Emperor Leopold I, under the conduct of His Most Serene Highness, the Duke of Lorraine, and the Elector of Bavaria. (London: Printed for Robert Clavell, 1686), 3. The treaty that the Ottomans broke was the Peace of Vasvar. led to a debate in academic scholarship over what reasons and causes during this time period led to the Ottoman decline.

Explanation for Ottoman Decline, 1683-1699: The Historical Controversy.

Contributing to a broader debate on the reasons for the decline of the Ottoman Empire, historians have provided a variety of explanations for the Empire's changing fortunes between 1683 and 1699. The scholarly writing that reflects this time period agrees that there were both European strengths and Ottoman weaknesses that contributed to the decline of the Ottoman Empire from 1683 to 1699 but scholars disagree as to what those strengths and weaknesses were. Some scholars argue that the European Military Revolution contributed to a new European military that was stronger than that of the Ottomans while others argue that the Holy League Alliance was Europe's greatest strength. Likewise scholars focus on different aspects of Ottoman weakness. Some argue that the traditional military style of the Ottomans limited their ability to advance militarily at the pace of the European armies while others argue that the new armies of Europe after the Military Revolution led to the Ottomans adopting some aspects of the Military Revolution which caused the decentralization of the Ottoman Empire's political system. Despite the differences in opinion, all scholarly writing that studies this period of European-Ottoman conflict accepts the historical idea that this was a time of Ottoman decline; however, scholars differ when trying to answer the question "why did this decline occur."

The Christian strengths demonstrated by studying military history and the political and diplomatic factors of the time period lead scholars to a variety of conclusions. The study of the seventeenth-century Military Revolution identifies some key military developments that helped propel the European armies to a level above the Ottomans. The technology and tactics of the military revolution were greatly encouraged by European generals such as Raimondo Montecuccoli of the Habsburg army who had modernized the Austrian army using the tactical reforms from the Thirty Years War. New tactics, such as the linear infantry formation, and new technologies, such as the flintlock musket, were new aspects of the Austrian army that were perfected by Eugene of Savoy. ${ }^{22}$ It is argued that these technological and tactical advances gave the European powers a decisive advantage during the early stages of the War of the Holy League. This view of European strength is an argument put forward by military scholars such as Jeremy Black whose main argument for Ottoman defeat in Europe during this time was caused by European advances in technology and battlefield tactics.

Another historian who believes the Military Revolution created a decisive gap between European and Ottoman capabilities is Geoffrey Parker. Geoffrey Parker observes three sources of Ottoman inadequacies that he argues contributed to the growing gap between European and Ottoman capabilities. Ottoman inferiority stemmed from difficulties in adopting new field tactics, modernizing metal production and adopting new gunpowder weapons into a

\footnotetext{
${ }^{22}$ Black, Jeremy. European Warfare 1660-1815. (London:
} Yale University Press, 1994), 105. 
traditional military framework. ${ }^{23}$ Using these inadequacies as evidence of Ottoman sluggish military transformations, historians like Geoffrey Parker argue that it was both the European adaptability to new styles of warfare and the Ottoman inability to adapt to the new military frameworks that were responsible for the Ottoman decline at the end of the seventeenth century. The conclusion to this analysis does not state a clear decision between Ottoman inferiority causing Ottoman decline or European superiority, but Parker does seem to place most of the blame on Ottoman inferiority through the language he uses throughout his essay. Phrases such as "the Turks never learned," or "Ottoman inadequacy" are used to describe the Ottomans when Parker compares their military framework with that of Europe. ${ }^{24}$ This language use suggests that Parker places the fault of the Ottoman decline on the Ottoman's inability to adopt a new military framework to compete with Europe.

A result of conclusions presented by Parker and Black is the scholarship of historians like Gabor Agoston and Rhoads Murphy whose studies test the validity of arguments presented by Parker and Black. Gabor Agoston disagrees with Parker's idea of Ottoman technological inferiority and argues that the Ottomans were not only capable at wielding firearms and new technology on the battlefield but were also leaders in gunpowder development. Agoston presents the Damascus twist barrel, a musket with a greater range and more accurate shot than a normal European made musket and which was a highly sought after weapon of war manufactured in the Ottoman Empire. ${ }^{25}$ The Damascus twist barrel is used by Agoston to argue that the Ottomans were in fact introducing new technologies that were on pace with the Europeans up until the mid-seventeenth century. Furthermore, Agoston points to the Janissary troops volley fire practice as "proof for their participation in the European Military Revolution." ${ }^{, 26}$ His article successfully shows examples of how Ottomans did in fact participate in the European Military Revolution and adapt militarily at a similar pace as the Europeans. Agoston also recognizes the Ottoman decline during the years 1683 to 1699 and argues that this was not caused by European military advancements in technology or tactics that the Ottomans could not master.

Instead of tactics and technology, victory on the battlefield, according to Agoston, depended on who had the advantage in troop size and number of deployed weaponry. $\mathrm{He}$ argues that the Ottomans were superior to their opponents in this aspect up until the end of the seventeenth century. ${ }^{27}$ This emphasis on the importance of the size of an army by Agoston leads his analysis of the European Military Revolution into a different study of the Revolution than what is focused on by Parker and Black. Using this aspect of the Military Revolution, Agoston attributes European success on

${ }^{23}$ Parker, Geoffrey. Europe and the Wider World, $1500-$ 1750: The Military Balance. (Urbana: University of Illinois Press, 1987), 18.

${ }^{24}$ Ibid., 18.

25 Agoston, Gabor. "Firearms and Military Adaptation: The Ottomans and the European Military Revolution, 14501800." Journal of World History. Volume 25, Issue 1, (2014), 105.

${ }^{26}$ Ibid., 97.

${ }^{27}$ Ibid., 109. the battlefield to Europe's ability, especially the Habsburgs, to raise armies that could logistically and numerically equal the armies of the Ottomans. In addition, Agoston puts a final emphasis on the Habsburgs' ability to lead an alliance and wage a coalition against the Ottomans, effectively forcing the Ottomans to fight a war on three fronts. Fighting on three fronts led to the Ottomans' inability to concentrate their forces on one battle. Instead they would have to divide their military, giving the Europeans a numerical advantage on the battlefield in the process. Agoston rejects the notion that Ottoman inferiority in gunpowder technology and tactics on the battlefield resulted in the empire's decline. However, he does argue that the Military Revolution was a sign of European strength in that the European armies could now supply and finance armies that were similar in size or even larger than the Ottoman armies, who traditionally had the bigger armies.

The European increases in numerical and logistical standing armies to a level equal with the Ottoman armies caused the Ottomans to reform their armies to adjust to the new military styles of Europe. However, Agoston argues that the military reforms introduced by the Ottomans to counterbalance the increased firepower and military efficiency of the Habsburg army proved to be disastrous for the Ottoman Empire. ${ }^{28}$ When the Ottoman military reformed to increase the size and strength equal to the Europeans it caused a complex shift in economic and social aspects of the empire. Peasants became deprived of community, formed groups of outlaws, and began local revolts. Additionally, the Ottoman government increased the number of soldiers recruited to the Janissary ranks which gave more man power to a group that already had a great deal of influence in politics because of their position within the army. They also began recruiting more from peasant populations within their empire but an increased peasant population armed with muskets made a rebelling peasant population more dangerous to the state. ${ }^{29}$ Hence, the argument put forward by Agoston recognizes that when aspects of the Military Revolution were brought to the Ottoman Empire it had a negative impact on the well-being of the empire rather than a positive one.

Like Agoston, Rhoads Murphy discusses the decline of the Ottoman power and agrees that the Ottomans were very capable of adapting militarily to the European Military Revolution. Murphy argues against Geoffrey Parker's notion that the Ottoman military structure was static and unable to reform. His analysis of Ottoman methods of supply to troops and fortresses on the battlefield is used to show that Ottoman armies were already ahead of new European developments in logistics and centralization. Murphy concludes that the Ottoman armies were in continuous revolution to gain more autonomy and state regulation, and rejects the notion that the development of the Ottoman military tradition was a static moment in Ottoman military history. ${ }^{30}$ Throughout his

\footnotetext{
${ }^{28}$ Agoston, Gabor. "Empires and Warfare in East-central Europe, 1550-1750 the Ottoman-Habsburg rivalry and military transformation," in European Warfare 1350-1750, ed. by Frank Tallett and D.J.B. Trim (New York: Cambridge University Press, 2010), 127.

${ }^{29}$ Ibid., 127.

${ }^{30}$ Rhoads Murphy, "Ottoman military organization in Southeastern Europe, c. 1420-1720," in European Warfare 1350-
} 
analysis, Murphy focuses on the bureaucratic and logistical sophistication of the Ottoman Empire, arguing that the Europeans were unable to match the Ottomans strength in this aspect of war. However, Murphy points out that when the Ottoman supply lines broke morale would quickly deteriorate. ${ }^{31}$ While recognizing the strength and superiority of Ottoman supply and logistical operations during war, Murphy argues that the Europeans successfully interfered with the supply capabilities of the Ottoman armies which resulted in a loss of morale from Ottoman troops fighting on the battlefield.

Furthermore, Murphy focuses on the effect of the Holy League Alliance from 1683 to 1699 on the conduct of war by the Ottoman army. He states "the characteristic pattern of warfare in the period between 1566 and 1683 before the era of the Sacred Alliance had been one dominated by localized conflicts, small scale engagements and the conduct of battle using fairly conventional methods." ${ }^{32}$ His argument reinforces the idea that the formation of a European alliance and the three prong attack on Ottoman territory hindered the Ottomans' ability to effectively supply their field armies. As already outlined, supply of Ottoman armies was vitally important for the morale of Ottoman soldiers but the combination of a three prong attack and attacks on Ottoman supply lines later on in the war had a devastating effect on the Ottoman Empire's ability to respond to the European advances. Overall, the Ottomans were well prepared and well supplied for the siege of Vienna and an Ottoman offensive but after the horrific defeat on the plains of Vienna they were illprepared for a defense of their European territory from the attacks of a European alliance.

Both Murphy and Agoston take up the challenge of refuting the idea of Ottoman inferiority in military operations at the end of the seventeenth century. The authors use examples of how the Ottomans not only kept up with European advances in warfare but also how they were considered leaders in effective military operations and tactics by the end of the seventeenth century. The authors are different however in their conclusions as to what caused the decline of the Ottoman Empire by 1699. Agoston argues that the size of armies fielded by the European powers finally reached numerical and logistical parity with the Ottoman armies by the start of the war in 1683. Furthermore, Agoston links the Ottoman state reforms implemented to create larger armies to political and social turmoil within the Empire. Murphy however, attributes the Ottoman decline to the three prong attack of the European nations and their ability to overstretch and harass Ottoman supply lines, causing Ottoman military operations to decline during the war. Although they disagree with the notion that the Ottoman Empire's military structure was incapable of evolving, the two scholars argue that new found strengths of the European armies caused the

1750, ed. by. Frank Tallett and D.J.B Trim (New York: Cambridge University Press, 2010), 157.

${ }^{31}$ Murphy describes how one of the most effective tactics against the Ottomans was deep penetration behind enemy lines to harass and do harm to the Ottoman supply line. This strategy he describes is argued to be very effective in the conduct of war against the Ottomans. Ibid., 154.

${ }^{32}$ Ibid., 11.
Ottomans to make reforms that hindered the empire rather than improved it.

The academic studies of Agoston and Murphy attempt to address the preconceived notion that the Ottoman military lacked the ability to evolve militarily and were stuck in a traditional static form of military operations. Both authors present arguments that focus on other aspects of the war and argue that other events had a more significant impact on Ottoman decline than this notion of Ottoman inability to adapt militarily. Although authors such as Agoston, Murphy, Parker, and Black wrestle with these ideas of Ottoman adaptability, the remainder of the academic studies that focus on this time period of Ottoman history look at the events in a broader picture and try to answer what events would affect the overall history of the Ottoman Empire. These scholars discuss the impact of the siege of Vienna and the subsequent formation of the Holy League Alliance, the social and political turmoil within the Ottoman Empire that plagued Istanbul and other areas of the empire, and the morale of European armies who believed for the first time that God was using them to punish the Ottomans.

To begin with, the point of Ottoman soldiers losing morale that is touched on by Rhoads Murphy is the topic of discussion for other scholars who have analyzed these events. An aspect of Ottoman history from 1683 to 1699 is the soldier mutinies and deposal of the Ottoman Sultan in 1687. By focusing on the army mutinies in 1686 and 1687 Caroline Finkel presents an image of the political and social turmoil that deterred the Ottoman military operations. Finkel tells the story of an Ottoman army that is caught split on two sides of a bridge when a terrible storm comes upon them and traps one half of the army without food or shelter from the elements. This event demoralized the Ottoman soldiers who were shortly thereafter told to winter in Belgrade where they would receive little supply during the winter. In response to these events the mutinous army marched to the Grand Vizier's camp and demanded his head. ${ }^{33}$ The impact of these events is important because it shows the type of political unrest that occurred, especially amongst the soldiers, within the Ottoman Empire from 1683 to 1699.

Furthermore, up until the siege of Vienna the Ottoman Empire was renowned for its centralized state and strong leadership either from the Sultan or from his Grand Viziers. After 1683, however, the defeats and social turmoil would lead to the disposal of Mehmed IV in 1687. Likewise, the leadership of the Ottomans at the siege of Vienna also comes under scrutiny from scholars who have studied the siege. With the centralized state of the Ottoman Empire making it more like a despotic medieval feudal system, the competence and abilities of both the Sultan and the Grand Vizier were vitally important. ${ }^{34}$ With this in mind some scholars do place some of the blame for Ottoman decline on the leaders of the Ottoman Empire who through their incompetence were either executed or deposed.

33 Caroline Finkel,. Osman's Dream: The Story of the Ottoman Empire 1300-192 (London: Jon Murphy Publishers, 2005), 193-195.

${ }^{34}$ A.N. Kurat, "The Reign of Mehmed IV, 1648-1687,"in A History of the Ottoman Empire to 1730, edited by Michael Cook (New York: Cambridge University Press, 1976), 161. 
The issue of Ottoman leadership for many scholars begins with the Grand Vizier and initiator of the siege of Vienna in 1683, Kara Mustafa. "Kara Mustafa came from a political dynasty of Grand Viziers from the Koprulu family who revived a decaying and dividing political system that threatened the collapse and fragmentation of the Empire." 35 Kara Mustafa's failure at the siege of Vienna would result in his death and earn him a place in history as a military leader whose crucial mistakes on the battlefield led to his army's catastrophic defeat on the plains outside the walls of Vienna. The Grand Vizier's disregard for fortifying his own siege position outside of the walls of Vienna or securing the heights that the relief force used for an artillery and attack position led to the Imperial Polish relief forces' devastating attack on the Ottoman army's exposed flank. ${ }^{36}$ Other factors must be considered in the Ottomans defeat; the courage and fighting spirit of the defenders, the unexpected response of the Polish to send a relief force, and the lack of heavy cannon brought to the siege by the Ottomans, all contributed to the Ottoman defeat at Vienna. Regardless of these factors, many scholars argue the lack of military experience of Kara Mustafa in siege warfare and his mistakes at the siege of Vienna were a key reason for the Ottoman defeat at Vienna in $1683 .{ }^{37}$

Other scholars have dedicated research to the formation of the Holy League Alliance and the effect on the outcome of the War that it had. Consisting of Venice, Poland, and the Habsburgs, the alliance effectively fielded a three way front against the Ottoman Empire that put pressure on Ottoman forces in a variety of locations. The beginnings of this alliance began before the siege of Vienna when Kara Mustafa and his enormous army kept his intended target a secret, thus forcing the formation of an alliance between the Habsburgs and Poland. Both European powers saw the advantage of a mutual alliance to ensure their own personal security from the mighty Ottoman army. ${ }^{38}$ This alliance was key in the victory at the siege of Vienna and without the Polish relief force history may have taken a different direction. The victory won on the plains outside the walls of Vienna would lead to the involvement of Venice. The city state of Venice, which had never been allied with the Habsburg Empire, would join the alliance in 1684, thus changing the fortunes of both Venice and the Habsburgs and very much for the better. ${ }^{39}$ The effect of this three part alliance would be the dramatic change in fortune for all three nations in their subsequent war with the Ottoman Empire.

Additionally, the victory at Vienna led to a European sense of a renewed crusade to recapture former Christian territories lost to the Ottomans since 1453. Seeing an

\footnotetext{
${ }^{35}$ Andrew Wheatcroft, The Enemy at the Gate, 37.

${ }^{36}$ Ibid., 139;,Geoffrey Parker, Europe and the Wider World, 1500 - 1750: The Military Balance. (Urbana: University of Illinois Press, 1987), 18.; Kenneth Setton, Venice, Austria, and the Turks in the Seventeenth Century. (Philadelphia: The American Philosophical Society, 1991), 267.

${ }^{37}$ Parker and Wheatcraft are the scholars who most strongly argue this point in their books. It is also touched on by Jeremy Black in his book European Warfare 1660-1815, 105.

38 Stoye, John. The Siege of Vienna. (London: Collins Publishing, 1964), 111.

39 Kenneth Setton, Venice, Austria, and the Turks in the Seventeenth Century, 260.
}

opportunity for the possibility of clearing the Ottoman and Barbary Corsairs' presence out of the Adriatic Sea, thus expanding European commerce, other Italian cities such as Ragusa sent financial and military support to the alliance. ${ }^{40}$ Even the Pope saw opportunity for the expansion of Catholic influence into Eastern Europe with the conquest of territory with a Catholic population. Accordingly, the Pope would send large sums of money and other support to the alliance and their cause. Consequently, the victory at Vienna for the Habsburgs and Poland led to the formation of a Christian alliance that had support from many other European nations including the Pope and trading cities such as Ragusa.

Although scholars focus on different aspects of the history from 1683 toOtt 1699, the Holy League Alliance is an underlying theme of almost all scholars. The alliance succeeded in putting a strain on Ottoman military operations since the Ottomans were used to operating in only one military theatre at a time. Forced to fight on three fronts, the Ottomans struggled to field armies that could match the size and logistical strength of a European army. The Holy League Alliance also had an advantage in morale because of the money given to the alliance by the Pope and other nations, and the rhetoric of a holy crusade that existed at the time. The Holy League Alliance gave the Europeans an advantage that they successfully exploited by winning several major victories from 1683 to 1699.

The task of sorting through the arguments and evidence presented by scholars in this debate around Ottoman decline after the siege of Vienna is a challenge. The disagreement among scholars and the focus on different issues has left some scholars on opposing sides of the debate. The writings of Rhoads Murphy and Gabor Agoston take up the challenge of exploring the accusation that the Ottomans failed to adapt to the European military revolution of the seventeenth century made by authors like Jeremy Black and Geoffrey Parker. Other scholars add to the discussion of Ottoman decline by considering different events and aspects of the war. The result of this debate is the identification of both European strengths and Ottoman weaknesses that lead to the decline of the Ottoman Empire. Scholars argue that European military adaptation could not be implemented by Ottoman armies because of their political structure, a notion that is rejected by other scholars in favour of the argument that Ottoman military reforms led to the decentralization of their political system. Likewise, the focus on the strength of the European alliance, the lack of leadership from the Ottoman heads of state, and the attitude of a renewed crusade are additional factors considered by scholars studying the decline of the Ottoman Empire. These differing points of view have created an academic debate among scholars regarding which events of the period prior to the 1683 and the subsequent years until 1699 played the biggest role in the decline of the Ottoman Empire.

\footnotetext{
${ }^{40}$ Caroline Finkel, Osman's Dream: The Story of the Ottoman Empire 1300-1923 (London: Jon Murphy Publishers, 2005), 279.
} 
Ottoman Decline, 1683-1699: An Assessment.

Having reviewed the historiography, as well as some of the primary sources, pertaining to the Ottoman reversals during this period, what conclusions can be drawn? A variety of arguments are presented by scholars, and all have contributed to the debate regarding the cause of Ottoman decline. Although Geoffrey Parker and Jeremy Black raise some interesting points in their articles, along with some contributions from Caroline Finkel and other scholars, their arguments concerning the inability of the Ottoman Empire to adapt militarily are less compelling than arguments from Agoston and Murphy. The decline of the Ottomans was much more complex than just the idea that Ottoman armies could not adapt to the Europeans. The Ottomans did adapt to the European Military Revolution but the subsequent decentralization of the Ottoman state and the importance of other factors like the Holy League Alliance helped create the Ottoman decline in Europe from 1683 to 1699.

Some aspects of Ottoman history before the siege of Vienna help provide some background to how the Ottomans viewed the events of the time. Before 1683 the only major defeat really suffered by the Ottomans was the battle of Lepanto. There are other Ottoman defeats but Lepanto is one that was celebrated throughout Europe for many years and probably the most praised victory against the Ottomans until the siege of Vienna in 1683. However, Ottoman expansion into Europe in its early history seemed like an Islamic steam roller destroying one European state after another. The Ottomans also treated the Europeans as their inferiors, forcing foreign envoys and diplomats to show signs of inferiority and humiliation when coming before the sultan, and refusing to sign bilateral agreements or treaties but only unilateral documents. ${ }^{41}$ The Ottomans certainly set the rules early on in their relations with the Europeans but all of this would change during the War of the Holy League.

By 1686 the Ottomans had suffered several major defeats and the European alliance was making territorial conquests in Hungary and other areas of the Ottoman Empire. "The scale of the defeats suffered in 1686 was such that, for the first time ever, the Ottoman Empire sought to initiate peace negotiations with its enemies, but approaches on the part of Grand Vizier Sari Suleyman Pasha prompted by the fall of Buda failed to elicit any interest." 42 Although it is hard to find any agreed upon conclusions regarding the cause for Ottoman decline it is important to note that this was a time period where the Ottomans wanted to stop fighting the Europeans and were willing to enter into negotiations that favoured the Europeans for the first time. There seem to be only two possible reasons for this attempted peace treaty. At the very least the Ottoman sought a breathing space to recover from the defeat at Vienna; at most, they recognized the need for a lasting peace because of the realization they could no longer cope with the new found strengths of the European armies and alliance.

${ }^{41}$ Edhem Eldem, "Foreigners at the Threshold of Felicity: the Reception of Foreigners in Ottoman Istanbul," in Cities and Cultural Exchange in Europe, 1400-1700, ed. by D. Calabi and S. Christensen (Cambridge: Cambridge University Press, 2007), 120.

${ }^{42}$ Caroline Finkel, Osman's Dream, 291.
Incidentally, the cohesion and strength of the European alliance between Venice, Poland, and the Habsburgs was quite rare in European history. Venice and Habsburg relations would change quit dramatically in that they had never been in an alliance before but after the siege of Vienna both sides agreed to an alliance that attacked the Ottomans both by land and by sea. ${ }^{43}$ Combine this alliance with the alliance already formed by Poland and the Habsburgs and the result was the formation of the Holy League Alliance that had three strong European nations receiving financial support from other European states and a religious fervor of re-conquest. This was a dramatic shift from the discontent and division of the European armies in earlier years of Ottoman conquest. Additionally, the religious fervor and thinking that God was with Christian Europe which was being used to punish the Ottomans for their sins continued not only until the end of the seventeenth century but into the eighteenth century with writers like Paul Rycaut. ${ }^{44}$ The Ottomans, even with their large armies, military adaptation, and exceptional supply lines could not match the numerical and moral superiority of the Europeans through the years of the Holy League Alliance's existence.

The Christian renewed crusade, as it was called by some, helped motivate soldiers to a level that was well above the spiraling deteriorating morale of Ottoman soldiers. This attitude of recapturing lands lost to the Ottomans through a renewed crusade was not just the outcome of a seen advantage after the siege of Vienna but also the fulfillment of a deep passionate desire in the Western Catholic world. ${ }^{45}$ With financial contributions from the Pope and troops sent to strengthen Catholic armies fighting the Ottomans, the Europeans showed a strong united front with financial support and religious zeal that lit a burning enthusiasm of war against the Ottomans. Supported by literature and stories of Christian triumphs over Islam, the European forces experienced a feeling of superiority to the Ottomans that they had never experienced before. The siege of Vienna and the fall of Kara Mustafa epitomized the ebbing Ottoman Empire. ${ }^{46}$ Literature and stories of Ottoman weakness spread throughout Europe and gave Christians further motivation to join the fight against the Islamic Empire threatening Eastern Europe. Conclusively, this attitude of renewed crusade by the Christian nations contributed to the strengths of the European armies and adds more evidence to the significance of the European Holy League Alliance and its role in the decline of the Ottoman Empire.

On a different note, the armies of the Habsburgs made the most significant advances into Ottoman held territory, advancing as far as Belgrade by 1688, and was successful in adopting armies that matched the strength in man power and weaponry of the Ottomans. Being able to match the strength and size of the Ottoman armies was a significant breakthrough for the Habsburgs and their allies. This increased man power combined with Habsburg superiority over fire power and tactics caused the Ottomans to increase their number of janissary gunners and recruitment of gun

\footnotetext{
43 Kenneth Setton, Venice, Austria, and the Turks in the Seventeenth Century, 260.

${ }^{44}$ Andrew Wheatcroft, The Enemy at the Gate, 75.

${ }^{45}$ Ibid., 190.

${ }^{46}$ Ibid., 201.
} 
carrying militia within the empire. ${ }^{47}$ Some of the impacts of the European Revolution was the centralized state and the formation of the state financed standing army. Both of these impacts led to the increased size of European standing armies and improved tactics that gave European armies an advantage over the Ottomans. Agoston's idea that the biggest factor toward victory on the battlefield is the numerical and logistical size of the army is supported by other military historians such as David Parrott. ${ }^{48}$ In view of this, the Europe success in creating and maintaining armies numerically and logistically equal or even superior to that of the Ottomans is a European strength that had a major effect on the decline of the Ottoman Empire.

It is evident that improved European strength through increased army strength, both logistically and numerically, forced the Ottomans to advance their own military system which caused the Ottoman Empire to decentralize. In other words, the strength of the European armies played a significant role in the development of Ottomans weakness that some scholars discuss in their writings. Europeans managed to field armies that could defeat Ottoman forces on the open battlefield forcing the Ottomans to adapt but in trying to adapt the Ottoman Empire became a decentralized state that decreased the power held by the Sultan in Istanbul, and the Empire experienced more social and political upheaval caused by the increased amount of fire-arms possession by peasants experiencing famine and other hardships. These new challenges faced by the Ottoman Empire limited their ability to reverse the outcome of European gains in Eastern Europe up until 1699. Additionally, the European alliance made things more difficult for the Ottomans in that they had to fight a war on three fronts against the enemy. All of these factors make a strong argument that the new developed strengths of the European armies fighting the Ottomans had a significant role that forced the Ottomans to try and make changes to their armies and administration which ultimately led to their decline in Eastern Europe.

With all of this in mind, it is important to address the question of how important was the War of the Holy League and the outcomes of this war to Ottoman history. As mentioned earlier, the Ottomans had suffered few defeats against the European up until 1683 and the defeats that they did suffer just momentarily stopped the Ottoman advance. The years after 1683 and until 1699 are the first serious signs of Ottoman decline. The struggles that the empire experienced during this time would have repercussions that would carry over into the eighteenth century. A number of key events in the early stages of Ottoman history in the eighteenth century

${ }^{47}$ This argument is taken from Agoston and his argument presented in the historiography.

Gabor Agoston, "Empires and Warfare in East-central Europe, $1550-1750$ the Ottoman-Habsburg rivalry and military transformation," in European Warfare 1350-1750, ed. by Frank Tallett and D.J.B. Trim. (New York: Cambridge University Press, 2010), 112.

${ }^{48}$ Parrott, David. "Strategy and Tactics in the Thirty Years War: The Military Revolution," in The Military Revolution Debate, edited by Clifford Rogers (Boulder: Westview Press, 1995), 227-252. show what kind of effects the period from 1683 to 1699 had on the Ottoman Empire.

In the first few years of the eighteenth century there was already discussion about how the Treaty of Carlowitz was a sign that the Ottomans were not the once mighty empire in Eastern Europe. By 1703 the attitude of Ottoman citizens saw the treaty of Carlowitz as a sign of weakness from the new Sultan, Mustafa II, who was accused of compromising Muslim honour by signing the peace treaty. ${ }^{49}$ With malcontent from rebellions and revolts, like the one in Edirne known as the Edirne Incident in 1703, continuing to pop up in the Ottoman Empire after the Treaty of Carlowitz in 1699 it is evident that Ottoman political and social turmoil continued into the eighteenth century. By the end of 1703 the Ottoman people, with help from the Janissaries, had deposed another Sultan and had replaced him with another member of the royal family. An empire which for so long had been a testament to the power of the centralized state had now become a place of constant political and social turmoil.

The War of the Holy League had also brought new terms of diplomatic relations between the Ottomans and the Europeans after the treaty of Carlowitz. "The European states came to realize that the Ottoman Empire no longer had the strength to challenge them as it had before and, as the eighteenth century wore on, diplomacy rather than military might increasingly set the terms of the Ottoman encounter with its European neighbours, as negotiation began to prevail over aggression as a way of resolving international differences." 50 The impact from the war that ended in 1699 was one that changed the diplomatic conduct and relational attitude of the European nations toward the Ottomans. The Ottomans had lost their dominant role as most powerful military in Eastern Europe. The decline of the Ottoman Empire from 1683 to 1699 has had a profound effect and provides a moment in history when a shift in diplomatic relations between two states began to change in a negative way for the Ottoman Empire. Their decline in power is reflected in this shift in diplomatic relations and the social and political turmoil that continued to ravage their nation in the beginnings of the eighteenth century.

\section{Conclusion:}

In hope of finding an adequate understanding of the Ottoman decline in Eastern Europe from 1683-1699, this essay has explored the events during this time through primary sources as well as recent scholarly work. There is no debate over whether there was in fact a decline in Ottoman power during this time. However, scholars are divided about what caused the decline of the Ottoman Empire. Furthermore, this essay has made the argument that European strengths and adaptations such as the strength of the Holy League Alliance, and the new military developments that improved European armies numerically and logistically are the foundations of European strengths that played a significant role in the decline of the Ottoman Empire. Moreover, these new European strengths forced the Ottomans to reform their military and state but the implemented reforms along with poor leadership helped cause the Ottoman Empire to weaken and, furthermore, begin to decline. Finally, it has been shown that

\footnotetext{
${ }^{49}$ Caroline Finkel, Osman's Dream, 330

${ }^{50}$ Ibid., 333.
} 
the losses to territory and sphere of influence suffered by the Ottomans in the years from 1683 to 1699 had a profound impact on the history of the Ottoman Empire, thus showing the importance of this time period when trying to understand the history of the Ottoman Empire.

\section{References}

Agoston, Gabor. "Empires and Warfare in East-central Europe, 1550-1750 the Ottoman-Habsburg rivalry and military transformation." European Warfare 1350-1750. Edited by Frank Tallett and D.J.B. Trim. New York: Cambridge University Press, 2010. 110-134.

Agoston, Gabor. "Firearms and Military Adaptation: The Ottomans and the European Military Revolution, 1450 1800." Journal of World History. Volume 25 Issue 1, (2014): 85-124.

Agoston, Gabor. "Habsburgs and Ottomans: Defense, Military Change and Shifts in Power." The Turkish Studies Association Bulletin, vol. 22, no. 1, (1998): 126-141.

Anon., A True Relation or Journal of the Siege and Taking by Storm of the Famous City of Belgrade by the Christian army under the conduct of the victorious elector of Bavaria, on the $6^{\text {th }}$ day of September 1688: with an account of its situation, fortifications, $\& c$., and also of the great victory gained by Prince Lovis of Baden over the Turkish army, commanded by the Bassa of Bosnia. London: Printed for Richard Baldwin, 1688 .

Anon., The Siege of Vienna by the Turks in 1683: Translated into Greek from an Italian Work Published Anonymously in the Year of the Siege. Translated by Jeremias Cacavelas. New York: Cambridge University Press, 1925.

Archer, Christon, John R. Ferris, Holger H. Herwig, Timothy H. E. Travers. A World History of Warfare. New York: University of Nebraska Press, 2008.

Bennridge, Will. An Historical description of the glorious conquest of the city of Buda, the capital city of the kingdom of Hungary, by the victorious arms of the thrice illustrious and invincible Emperor Leopold I, under the conduct of His Most Serene Highness, the Duke of Lorraine, and the Elector of Bavaria. London: Printed for Robert Clavell, 1686.

Black, Jeremy. European Warfare 1660-1815. London: Yale University Press, 1994.
Eldem, Edhem. "Foreigners at the Threshold of Felicity: the Reception of Foreigners in Ottoman Istanbul." Cities and Cultural Exchange in Europe, 14001700, ed. by D. Calabi and S. Christensen (Cambridge: Cambridge University Press, 2007), 114-31.

Eugene of Savoy. Memoirs of Prince Eugene of Savoy. Translated by William Mudford. New York: Printed for Henry Colburn, 1811.

Finkel, Caroline. Osman's Dream: The Story of the Ottoman Empire 1300-1923. London: Jon Murphy Publishers, 2005.

Kurat, A.N. "The Reign of Mehmed IV, 1648-1687." A History of the Ottoman Empire to 1730. Edited by Michael Cook. New York: Cambridge University Press, 1976. 157-177.

Kurat, A.N. J.S. Bromley. "The Retreat of the Turks, 16831730." A History of the Ottoman Empire to 1730. Edited by Michael Cook. New York: Cambridge University Press, 1976.

Murphy, Rhoads. "Ottoman military organization in Southeastern Europe, c. 1420-1720.” European Warfare 1350-1750. Ed. Frank Tallett and D.J.B Trim. New York: Cambridge University Press, 2010. 135-157.

Murphy, Rhoads. Ottoman Warfare 1500-1700. New Jersey: Rutgers University Press New Brunswick, 1999.

Parker, Geoffrey. Europe and the Wider World, 1500 - 1750: The Military Balance. Urbana: University of Illinois Press, 1987.

Parrott, David. "Strategy and Tactics in the Thirty Years War: The Military Revolution." The Military Revolution Debate. Edited by Clifford Rogers. Boulder: Westview Press, 1995. 227-252.

Setton, Kenneth. Venice, Austria, and the Turks in the Seventeenth Century. Philadelphia: The American Philosophical Society, 1991.

Stoye, John. The Siege of Vienna. London: Collins Publishing, 1964.

Treaty of Carlowitz, 1699. Documents Archive. Available at www.fas.nus.edu.sg. Accessed March 102016.

Vaelckern, Johann Peter von. A Relation or Diary of the Siege of Vienna. New York: Union Theological Seminary, 1684.

Wheatcroft, Andrew. The Enemy at the Gate: Habsburgs, Ottomans and the Battle for Europe. Np: Vintage Digital, 2009. 